\title{
INTERCULTURAL COMMUNICATIVE SKILLS: PROGRESS ANALYSIS
}

\section{O. Zotova-Sadylo}

Kryvyi Rih National University

vul. V. Matusevycha, 11, Kryvyi Rih, 50000, Ukraine. E-mail:hjzotova74@ukr.net

Purpose. Having conducted a review of scientific literature, we have highlighted the link between the high level of communicative culture from the perspective of international business communication and professional realization of university graduates. The purpose of this study is to reveal the intercultural business communication proficiency of the university students and to identify the ways to improve communicative culture of the students within existing frameworks. Methodology. To find out the level of students' interest in communicative culture to cope with communicative problems in the process of business communication we have applied survey research. The purposes of the study identified the goals of the questionnaire. They are: 1) to diagnose the level of student's interest in the subject of the study; 2) to indicate the level of proficiency in the theoretical aspect of the study and its projection in practical aspect.112 participants from different specialties have been engaged in the study. Results. A questionnaire survey has revealed that the students are interested in the researched problem and they realized the role of intercultural aspect of business communication in their future career. It has found that the students expect the training process to be closely connected with the perspectives of their future professional work as well as communication for the cultural purposes. Still, the study shows that only about one-third of the respondents are ready to communicate on different topics in a foreign language. It approves the low level of foreign language knowledge and skills. Originality. Based on the analysis, we have defined communicative creativity as an instrument of effective professional communication. Communicative creativity is based on high language proficiency. It includes fluency in native and foreign languages, appropriate using of linguistic resources (lexicons, terminology, etc.), and ability to accompany the speech with nonverbal elements, quick mental processing, good imagination and creativity. The findings of the study have disclosed that the special courses focused on improving specific knowledge, skills and competencies are in demand. Practical value. To address learners' needs we have developed the special course "Business Communication" provides a great variety of intercultural communicative culture practice for students.

Key words: communicative culture; intercultural communication; questionnaire survey; communicative creativity; business communication.

\section{НАВИЧКИ МІЖКУЛЬТУРНОГО СПІЛКУВАННЯ : СТАН СПРАВ НА ПРАКТИЦІ}

\section{О. Ю. Зотова-Садило}

Криворізький національний університет

вул. В. Матусевича, 11, м. Кривий Ріг, 50000, Україна, E-mail:hjzotova74@ukr.net

Аналіз першоджерел виявив певний зв'язок між високим рівнем комунікативної культури в контексті міжкультурного ділового спілкування та професійною реалізацією випускників вищих навчальних закладів. Мета даного дослідження полягає у тому, щоб висвітлити рівень володіння міжкультурним спілкуванням студентами та запропонувати шляхи підвищення рівня міжкультурної ділової комунікації за існуючих умов. Щоб з'ясувати рівень зацікавленості студентів у навчанні комунікативній культурі з метою вирішення професійних завдань, ми розробили відповідну анкету. Мета дослідження визначила завдання анкетування, а саме: 1) продіагностувати рівень інтересу студентів до предмету дослідження; 2) визначити рівень володіння теоретичним та практичним аспектами проблеми. 112 студентів різних спеціальностей взяли участь у дослідженні. Анкетування засвідчило зацікавленість студентів у предметі дослідження та усвідомлення ними ролі міжкультурного аспекту ділового спілкування для успішного кар'єрного зростання. Результати анкетування продемонстрували очікування студентів щодо інтегрування у навчальний процес комунікативної професійної складової та комунікації з метою культурного обміну. Поряд з тим аналіз результатів дослідження показав, що лише одна третя респондентів підготовлена до комунікації іноземною мовою. Це доводить низький рівень володіння іноземними мовами на даному етапі. На підгрунті проведеного аналізу визначено комунікативну креативність як інструмент продуктивної професійної комунікації. Основою комунікативної креативності є досконале володіння рідною та іноземною мовами, а саме: відповідне вживання лінгвістичних одиниць (лексики, термінології тощо), здатність до застосування невербальних елементів у мовленні, швидкість ментальних процесів, розвинута уява та творчість. Відповіді учасників експерименту підтвердили нашу гіпотезу щодо затребуваності спеціальних курсів, які фокусуються на удосконаленні специфічних знань, умінь та компетентностей. У відповідь на запит студентів ми розробили спецкурс «Ділове спілкування», який має практичну спрямованість в аспекті удосконалення міжкультурного аспекту комунікативної культури.

Ключові слова: комунікативна культура; міжкультурна комунікація; анкетування; комунікативна креативність; ділове спілкування.

PROBLEM STATEMENT. Ukraine is on the way of economic and political reintegration into European Union. The government is encouraging the aspiration of individuals to improve their communicative skills. Nowadays, however, the level of proficiency in foreign languages in our country is extremely low in comparison with other European nations. According to the British Council and the Association of Innovative and Digital Education, about $7 \%$ of our fellow citizens are fluent in English [1].Considering the power of the lan- 
guage, we should put in place more instrumental measures. Investing in human capital through educational policy has been a growing priority for developing countries that ultimately foster economic growth [2].

This explains why providing students with high level of communicative competence, particularly, communicative culture and speaking at least one foreign language is key challenge for higher education in globalized environment. According to A Framework for Qualifications of the European Higher Education Area [3] "The competence of communication in foreign language is based on the ability to speak, understand oral speech, read and write - in other words, to function in the appropriate social and cultural context". It means literally to operate digital devices via use of English (as a common language of intercultural communication) to maintain formal / informal correspondence, to adapt the operation manual, to support telephone conversation and so on. This means that future professionals should obtain the skills and knowledge for effective communicative interaction in poly cultural environment. It is expected not only knowledge of English grammar and vocabulary but awareness in the field of cultural and linguistic diversity and pluralism, nonverbal language specific features and behavioral philosophy. In a nutshell, students should be proficient in intercultural communication and communicative culture.

The challenge is to do it within the existing curriculum. Current realities in technical and economic (nonlinguistic) Higher Educational Institutions are as follows: one or two hours per week devoted to the foreign language course in the first year and one hour per week or even fortnight as a part of Master's program. Such a minimum hours of foreign-language education are unlikely to be sufficient to reach an adequate level of the communicative competence for the students. This state of affairs comes in for criticism from scientists and practitioners but actually the situation has remained unchanged. Practice attests to the fact that the highest standards of professional development, communicative effectiveness and language competence are demanded by employers. In response to the challenges of the time in terms of high standards of communication skills, university teacher should develop a course of English for Specific Purposes (ESP) which, on the one hand, corresponds to his teaching strategy and methods but, on the other hand, it should be targeted on boosting students' language proficiency (competence) an occupationspecific field despite time constraints.

The objectives of the article are to highlight the students' proficiency in the aspect of communicative culture / intercultural communication and analyze the possible ways to improve communicative culture of the students with regard to an overcrowded curriculum and imperfect time allotted.

Analysis of Recent Research. It is necessary to clarify the terms communicative culture and intercultural communication. The notion "communicative culture" has long been a question of great interest in a wide range of fields like linguistic, pedagogical science, psychology. Even so, the term hasn't been defined clearly in the pedagogical and psychological dictionaries so far. The elements of the word collocation "communicative culture" namely "communication" and "culture" are investigated widely by Ukrainian and foreign scientists and as well as their definitions are presented in various types of dictionaries. According to Big Explanatory Dictionary of Modern Ukrainian Language "communicativeness is an ability to communicate, contact; relationship, communication, contacts among somebody or something, communicability [4]." The authors of "Ukrainian Pedagogical Dictionary" differentiate the term "communicability" and distinguish it as the main among conjugate ones. "Communicability" is claimed to be a person's ability to communicate with other people and amiability. Communicability is not inborn characteristic it is being formed as a result of person's activity in a social group and influence of the environment [5]. Culture is defined as education, accomplishments and a high level of excellence in any business or mental activities [4]. In addition, Ukrainian Pedagogical Dictionary determines culture of language as "...commitment to the norms of pronunciation, word usage and sentence construction». Based on comparative analysis of the definitions, we can summarize that the "communicative culture" is much broader notion than "culture of language" and it combines language and speech elements, psychological and creative components [5]. In fact, communicative culture implies skills of communicating and dialogic interaction that is really necessary to professionals in any field of work.

Special aspects of communicative culture in professional occupation are studied by the linguists Babych, N. D., Kapeliusshnyǐ, Zaretscka. Akkas\& Coker, Gez N., Gnawali, L., Passov E., Sitar, Černe, Aleksić, \&Mihelič have developed practical methods and approaches for education in communicative culture and intercultural communication [6-13]. While appreciating the experience let us note that practice of teaching, including engineering and economics students, still has faced challenges.

In our view, language creativity, linguistic guessing and intuition are creative components of communicative culture as well. The high level of linguistic intuition as the component of creativity gives impetus to communicative improvisation in aspect of realizing, perception, prediction and constructing an utterance. We can suggest that based on synthesizing logical and creative ways of lingual activity is possible to develop students' communicative culture and its multicultural aspect.

There are a large number of published studies (e.g.VanGundy, Maksymenko, Sergeeva) that describe practical methods of developing creativity. They declare creativeness as person's inborn talent but lost during process of growing up [14-16]. The educationaims to recover and improve an ability to create something new, nonstandard [14]. Their ideas can be applied and adapted to formation of engineering and economics students' communicative creativity as well.

Elizabeth Paton has been investigating the impact of media on people who create media texts in the terms of interaction of media effects and creativity [17]. Furthermore, Nicole Podschuweit considers that media coverage provides topics, arguments, opinions, and patterns of behaviour that participants can practice in their everyday and business communicative interaction [18]. 
Doroshuk, Novoselov deal with another dimension of the problem, in particular, they suppose that the communicative resources of creativity enhance the efficiency of professional business communication [19]. They consider the case method and business games as the effective way to improve business communication skills. LarysaRudenko focuses on communicative culture formation of future specialist in the service industry [20]. She determines creativity as the keystone to a person's successful communicative activity. It is one of the clue components of cooperation inside the social group. Ginsburgh\& Weber study interrelations between language diversity, multicultural societies and economic environment in conditions of globalization [21].

In view of all that has been mentioned so far, we may suppose that creativeness is a common feature of creativity, which characterizes an individual as a whole. The background of the creative process is an ability to break the mould along job tasks solving. Creativeness presupposes a new vision of reality, coping with typical perception, thinking, operation and also capability to excel and to pursue life-long learning.

In our opinion, communicative creativity is an integrated ability of a person to produce new ideas in virtue of well-formed communicative culture, an ability to develop, use and vary the language material creatively to resolve the problem. The peculiarities of communicative creativity in intercultural communication are basic level of language knowledge and skills, background experience, linguistic competence, positive motivation to learn foreign language communication in the professional field.

MATERIALS AND RESULTS. Having discussed the theoretical aspect of the issue, let us now turn to the practical implementation of the problem in High Educational Establishments in Ukraine. According to the objectives of the article we defined the targets at this stage of the research. They are: 1) to diagnose the level of student's interest in the subject of the study; 2) to indicate the level of proficiency in the theoretical aspect of the study and its projection in practical aspect.

We were trying to figure out how well the students were aware of the need of communicative culture to solve the interpersonal communicative problems, and if they were able to use the communicative creativity in intercultural communication. To test the state of affairs in practice, we have applied survey research method because it allows to collect data and to get direct feedback from respondents. That is why we have developed the questionnaire. It has included both theoretical and practical blocks [17]. According to our prognosis, the survey makes it possible to indicate the intercultural communication proficiency of the future professionals, to identify communicative creativity of the students and their readiness to practice it. The following part of this paper describes in greater detail the students' survey responses regarding to the researching problem.

Participants The fourth and the second-year students from different specialties of Kryvyi Rih National University have been invited to respond to a survey in order to identify an individual's actual knowledge, skills and competencies in intercultural communicative culture. At the beginning of the study, students were informed about its goals, and they agreed to cooperate on a voluntary basis. There were 112 students involved. Background information is provided in a Tab. 1 and Tab. 2 .

Table 1-Gender composition of survey participants

\begin{tabular}{|l|c|c|}
\hline \multicolumn{1}{|c|}{ Gender } & Quantity & $\%$ \\
\hline Female & 45 & 40 \\
\hline Male & 67 & 60 \\
\hline Total & 112 & 100 \\
\hline
\end{tabular}

Table 2 - Peculiarities of respondents' distribution according to the majors

\begin{tabular}{|l|c|c|}
\hline \multicolumn{1}{|c|}{ Specialty } & Quantity & $\%$ \\
\hline Economics & 38 & 34 \\
\hline Geodesy and Land Surveying & 19 & 17 \\
\hline IT Technologies & 16 & 14 \\
\hline $\begin{array}{l}\text { Power systems Engineering, } \\
\begin{array}{l}\text { Electrical and Mechanical } \\
\text { Engineering }\end{array}\end{array}$ & 25 & 22 \\
\hline Environmental Science & 14 & 13 \\
\hline Total & 112 & 100 \\
\hline
\end{tabular}

Apparatus and materials. A survey has been prepared with a view to collecting data of development of communicative culture / intercultural communication of the university students in practice. As provided by the tasks and goals of our study, we have drafted the questionnaire. The students are expected to give extended answers rather than "yes," "no" responses. In such a way, we have tried to motivate the respondents to show off the depth of their knowledge and to express the subjective attitude towards the problem of the study. We should mention that students could choose the language to reply to the questionnaire (native or foreign languages). It was the challenge of the survey. Corresponding results are provided in Table 3.

Table 3 - Respondents' distribution according to language of answers

\begin{tabular}{|l|c|c|c|c|c|c|}
\hline \multirow{2}{*}{\multicolumn{1}{c|}{ Student's Major }} & \multicolumn{2}{c|}{$\begin{array}{c}\text { Answers in foreign } \\
\text { language }\end{array}$} & \multicolumn{2}{c|}{ Both languages } & \multicolumn{2}{c|}{$\begin{array}{c}\text { Answers in native } \\
\text { language }\end{array}$} \\
\cline { 2 - 7 } & Quantity & $\%$ & Quantity & $\%$ & Quantity & $\%$ \\
\hline Economics & 12 & & 16 & & 10 & 8 \\
\hline Geodesy and Land Surveying & 2 & & 9 & & 3 & \\
\hline IT Technologies & 3 & & 10 & & & 3 \\
\hline $\begin{array}{l}\text { Power Systems Engineering, Electrical } \\
\text { and Mechanical Engineering }\end{array}$ & 1 & & 12 & & 3 & 36 \\
\hline Environmental Science & 2 & & 9 & & 36 & 36 \\
\hline Total & 20 & 18 & 56 & 50 & 36 \\
\hline
\end{tabular}


Results Analysis of theoretic block. Let us analyze the questionnaire results. As for the questions of this block "What is communicative culture / intercultural communication? What are their peculiarities?" "What does it mean "speech improvisation?" "Do you think it is necessary to be skillful in operating these notions and appropriate communicative knowledge and abilities in your future carrier?" The survey revealed that the percentage of students, who realized the meaning of the notions and are able to characterize them highlighting their features, is $21 \%$. Nearly half of the respondents $(48 \%)$ represented their replies at the intuitive or common-sense level, enforced their thoughts with appropriate notions and examples, but in general they cope with the task. Another group of respondents could not answer properly or replied in a formal way, for example, "... speech improvisation is ...when you improvise in your speech," their percentages equal $23 \%$. The rest of respondents didn't reply anything (8\%). It stands to mention that despite the discrepancy of knowledge among 112 participants, who completed the questionnaire, vast majority $(96 \%)$ are persuaded of the crucial role of communicative culture, its creative component and intercultural communication skills in future professional activity. $4 \%$ of people in the survey were not really interested in research subject.

To develop teaching and learning program as the next stage of the study, we proposed our students to design a model of a competitive professional, in the free form (as a chart, table or essay) (Fig. 1). Applying a method of analytical summarizing for these data, we calculated percentage of each important component then we recorded the features and characteristics which the students considered the most meaningful for a future expert. As a result of analysis and generalization we have constructed a round chart.

\section{A model of a competitive professional}

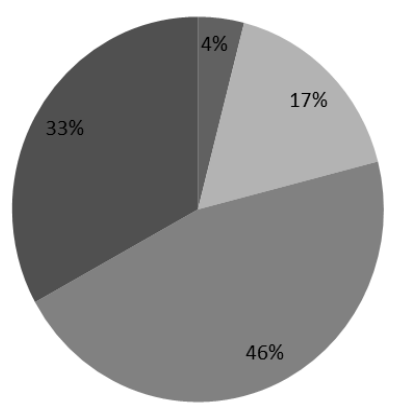

- Tendency to lifelong learning Multiculturalism

- Special professional knowledge

- Communicative competence

Figure 1 - Diagrammatic representations of students' ideas about a modern competitive professional

Let us further detail the components of the diagram. Communicative competence unifies such characteristics of future professionals as the language proficiency (foreign and mother tongues), ability to express their thoughts clearly and accurately, flexibility in decision making and effectiveness of communication.

A share of multiculturalism involves a person's spirituality, knowledge in the field of world literature, history, art, cultural heritage, modern music and theatre, reli- gious tolerance and respectful treatment to the alternative way of thinking. Besides, this category includes foreign language communication skills to facilitate connecting business partners on the "Subject-to-Subject" pattern.

It is important to point out that there is a segment Tendencytolifelonglearning in the students' model. This confirms conscious students' attitude to selfdevelopment in the professional field. What is of concern is that, only a small part of them (4\%) are ready to improve their potential. The goal of humanitarian subjects is to outline a range of priorities and to provide students with the skills of lifelong learning.

It is only natural that, all the respondents have included professional knowledge in their model. Special skills and abilities are the most important component of future successful career.

As illustrated in figure 1, communicative segment is the second important factor of career development from the point of view of the participants. The students have realized that high-qualified specialist uses the language not just as a means of communication but as a tool to decode an idea into the words, to express his inspiration in an understandable way to the public. Unfortunately, the students haven't integrated any creative characteristics into their model. The omission of this segment confirms they don't understand the role of creative intellect in solving professional problems and making the right decisions. We are sure that creativity gives an opportunity to transform basic knowledge into creative product and advanced solution of all kinds of the client's tasks for which consumers and employers are willing to pay. The respondents have completely neglected value, motivational and ethical standards. Despite the model imperfection, it has noted clearly students' common needs and aspirations concerning their future career prospects.

Now proceed to the practical block of the survey. The students have been suggested to choose one of three communicative situations and to provide feedback on it. The problem-based situations are targeted to check up critical thinking skills and encourage their speech creativity.

It is instructive to note that 35 out of 112 respondents (approximately $31 \%$ ) have taken an interest in and replied to all the communicative tasks. Their answers can be estimated as well reasoned in terms of style and appropriate to the context. In our view, these students have proved their communicative creativity in practice through their ability to produce different behavior patterns, flexibility of behavioral techniques, non-standard and efficient ways to solve the problem. Speech improvisation techniques often become necessary to resolve conflicts, for example. The appropriate level of communicative culture and speech improvisation raises the possibility of altering the climate of negotiations and transforming an opponent into a like-minded person. These skills are indisputable value for modern specialists in any industry.

About $25 \%$ of participants have provided their respo nses at least on one of the suggested situations successfu lly in appropriate style using humorous expressions as o ne of the way of preventing conflicts. 
Less than half of those surveyed (about 44\%) have $\mathrm{n}$ ot done that task properly or made too many mistakes to understand their point.

Further analysis has revealed that majority of students of different specialties possess basic skills of communicative culture required to facilitate communication among business partners. By the way, among 50 participants, who accomplished previous tasks in a foreign language or the mixed way, wrote their answers on the problem situation in the native language. Only 20 students $(18 \%)$ were capable to give the answers in English. Generally, it proves ill-preparedness of the students to intercultural communication and communicative creativity practices.

The next assignment is expected to check associative thinking as a component of communicative creativity and communicative culture of international communication. The additional aim of the task is to assess actual students' knowledge of a foreign language for specific purposes. The task contentvaried depending on student's specialization. This is an example for students of Economics. They are expected to form the word collocations with the verbs presented below and a noun; then to put them in the wright chronological order: "NEGOTIATIONS break off, complete, conduct, resume, and enter into."

We will present the results: 22 participants $(20 \%)$ constructed the associative chain correctly, 28 students (25\%) made little mistakes. The rest of respondents (62 students $-55 \%$ ) had considerable difficulties while doing that task. The results, therefore, have confirmed the overwhelming majority of respondents have a low to medium level of communicative skills in foreign language for specific purposes. That is why future professional straining should focus on building communicative competence.

The last question of the survey has been targeted on acknowledging students' opinions about the way of solving the problem of their practicing. That is the question "What subject would you add to the training course which could help you to communicate in the professional sphere successfully?" The students supposed that $5 \%$ of them need additional knowledge in the Ukrainian Language, as it is their mother tongue, other 5\% preferred "Psychology of Business Contacts" course, 8\% determined Foreign Language classes as the defining one, $3 \%$ would like to learn marketing and public relations, $2 \%$ wished to be more experienced in scientific research methods, $19 \%$ also sought to participate in workshops and trainings on the subject; $11 \%$ were satisfied with the current situation, and $47 \%$ emphasized the need to consider the creation of special study course that would include some elements of different humanitarian disciplines. Consequently, the results of ascertaining study have underlined the need to develop a synthesized special course with elements of Psychology, Logics, Conflict Management and Declamation targeted on future specialists practicing in communication within the working team, with the manager and consumers, and intercultural communication with foreign partners. Proportional allotment of the disciplines in accordance with the students' choice is represented in Fig. 2.

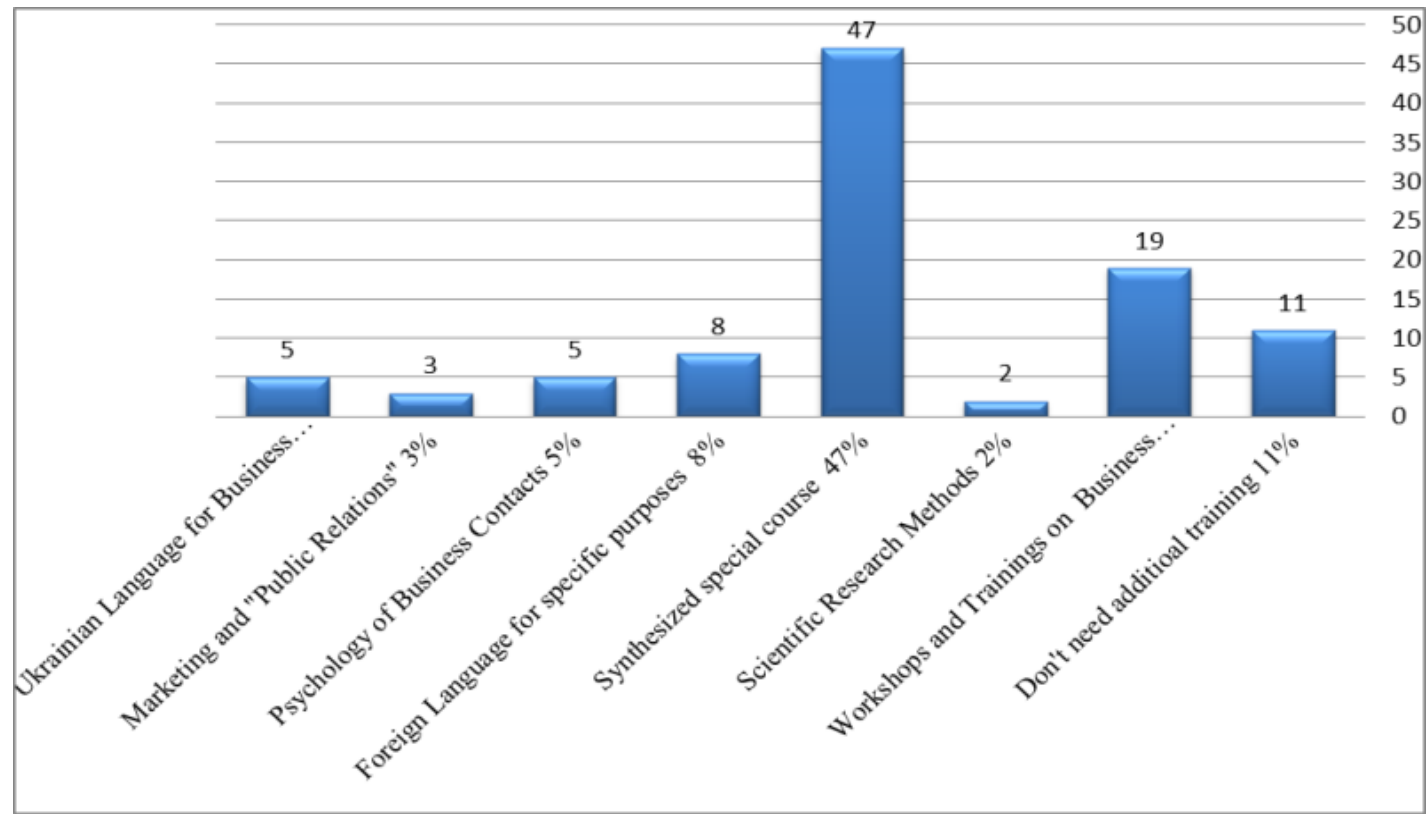

Figure 2 - Students' answers to Question 5

Different professional interests of the interviewers determine the scope of communicative creativity practical application. For example, both economists and environmentalists should be trained in business discussion, negotiating, discoursing, holding press-conferences, and business letter writing. However, aforementioned skills are not crucial for IT specialists or electrical and mechanical engineers. Signs and formulas are prevalent in professional communication of programming specialists, for instance. Their speaking should be brief, author- itative and facts-supported. Overall, the characteristic feature of communicative creativity is the differentiation of professional expertise, knowledge and skills depending on students' major.

In our view, communicative creativity is reflected in person's ability to screen a word fast and spontaneously, to use linguistic units or collocations with the aim of one's opinion expressing, keeping the conversation at the appropriate level in different forms (oral, writing, on-line, etc.). Communicative creativity includes high 
language proficiency (native or foreign language skills). It involves fluency in foreign language, rich vocabulary, quick mental processing, developed imagination, ability to use body language, tropes and tone, etc.

So a highly qualified specialist should be able to use the language as an instrument of effective professional communication. Higher education system has to train a student in practical applying of communicative creativity as the means of turning new ideas into the words and implementing of one's inspiration into a commonly acceptable verbal form. It sounds optimistic for perspective of our research. We are sure that communicative creativity and communicative culture in the context of international business communication are able to transform basic knowledge into creative product or nonstandard way to solve the problem. It is also significant that employers are prepared to pay for the abovementioned skills. On the other hand, lack of communicative skills can be a real barrier for all stakeholders in business professional communication. It could possibly cause limited ability to analyze the situation fast, shift from one thing to another and produce new ideas.

Since the stage of the study was limited to the previous objectives, we can make such a conclusion:

The main goal of the current study was to determine the level of students' interest in learning to intercultural communication and the level of implementation or nonimplementation skills of communicative creativity as a component of professional business communication. The research has shown that the students are intensely interested in training their communicative culture skills (96\% of respondents are positive about the options). With the regard to the awareness of the theoretical aspects of the problem, $69 \%$ of interviewers have shown off their knowledge in varying degrees. This is the evidence of general non-goal-oriented teaching of Humanitarian disciplines. With regards to the practical tasks of the questionnaire, unfortunately, approximately half of the students have shown a very low level of achievement. The results of answers in a foreign language have proven to be absolutely disappointing (18\% have seen the task to completion).

The findings of this research suggest that in order to understand the interference of language creativity and intercultural communication skills, it becomes necessary to take the interdisciplinary or multi-componential approach to future professional's training. We defend efficiency of synthesizing humanitarian disciplines, professional disciplines and implementation the integrating courses in the higher-education system. The findings of the study have disclosed that the special courses focused on improving specific knowledge, skills and competencies are in demand. An illustrative example is our author's special course "Business Communication" [22]. Integrating principles make available a new level of professional training for students. It ensures the longterm success in future business activity. Further experimental investigation is needed to estimate the effectiveness of the author special course which aim is to develop and improve the skills of communicative culture / communicative creativity in terms of intercultural communication.

\section{REFERENCES}

1. Keryk, O. (2017, September 5), In Ukraine Massive Campaign of Foreign Languages Learning Started. Retrieved December 17, 2018, from https://www.ukrinform.ua/rubric-other_news/2299136v-ukraini-startue-masova-kampania-vivcennainozemnih-mov.html.

2. Masino, S., Niño-Zarazúa, M. (2016), What works to improve the quality of student learning in developing countries? International Journal of Educational Development, 48, pp. 53-65. doi:10.1016/j.ijedudev.2015.11.012.

3. Framework Qualifications of the European Higher Education Area (revised 2018). 2018, Retrieved from : https://ufm.dk/en/education/recognition-andtransparency/transparency-tools/qualifications-

frameworks/other-qualifications-frameworks/qf-for-theeuropean-higher-education-area.

4. Busel, V. T. (2005), Vely`ky`j tlumachny`j slovny`k suchasnoyi ukrayins`koyi movy` (z dod. idopov.) [Big explanatory dictionary of modern Ukrainian language)], Kyiv; Irpin: WTF "Perun" Publ., 1728 p.

5. Goncharenko, S. U. (1997), Ukrainsky Pedagogichny Slovnyk [Ukrainian Pedagogical Dictionary]. Kyiv, Ukraine: Lybid. - 376 p. (in Ukrainian). Retrieved from: http://irbis-nbuv.gov.ua/cgibin/ua/elib.exe?Z21ID =\&I21DBN=UKRLIB \&P21DBN $=\mathrm{UKRLIB} \& \mathrm{~S} 21 \mathrm{STN}=1 \& \mathrm{~S} 21 \mathrm{REF}=10 \& \mathrm{~S} 21 \mathrm{FMT}=$ onlin e_book \&C21COM=S\&S21CNR=20\&S21P01 $=0 \& S 21 \mathrm{P}$ $02=0 \& S 21 \mathrm{P} 03=\mathrm{FF}=\& \mathrm{~S} 21 \mathrm{STR}=\mathrm{ukr} 0004069$ ISBN 96606-0002-X.

6. Babych, N. D. (2003), Praktychna stylistyka I kultura ukrayinskoy imovy [Practical Stylistics of the Ukrainian Language], Lviv, Ukraine: Svit. ISBN 9666031922.

7. Kape Tiusshnyĭ, A. O. (2007), Praktychna stylistyka ukraïns'koï movy: Navchal'nyı posibnyk. [Practical Stylistic of the Ukrainian Language], L'viv: PAIS.

8. Zaretscka, I. (2018), Komunikatyvna kultura yak component pedagogichnoi kultury [Communicative Culture as a Component of Pedagogical Culture], Retrieved March 27, 2018, from http://osvita.ua/vnz/reports/pedagog/1139/ from http://osvita.ua/vnz/reports/pedagog/1139/

9. Akkas, F. D., Coker, B. (2016), The Use of Communicative Approach in 9th Grade EFL Classes. Eurasian Journal of Educational Research, 16(65), 1-35. doi:10.14689/ejer.2016.65.05.

10. Gez, N. I. (2008), Istoriya zarubezhnoy metodiki prepodavaniya inostrannyh yazykov [History of international methodology for foreign language teaching], Moskow, Russia: Akademiya. ISBN 978-57695-4653-2.

11. Gnawali, L. (2010), The Communicative Approach to English Language Teaching, Journal of NELTA, 4(1). doi:10.3126/nelta.v4i1.3776

12. Passov, Y. I. Kuzovleva, N. E. (2010), Urok Inostannogo yazyka [Lesson of Foreign Language], Rostov n/D :Fenix, M : Glossa-Press, Retrieved from : https://www.twirpx.com/file/615507/.

13. Sitar, A. S., Černe, M., Aleksić, D., Mihelič, K. K. (2016), Individual Learning Styles and Creativity, Crea- 
tivity Research Journal, 28(3), 334-341. doi:10.1080/10400419.2016.1195651.

14. VanGundy, A. B., Naiman, L. (2010), Orchestrating collaboration at work: Using music, improve, storytelling, and other arts to improve teamwork, San Francisco: Jossey-Bass/Pfeiffer, Retrieved from: www.creativityatwork.com/CWServices/lnbio.htm $30 \mathrm{k}$.

15. Maksymenko, S. D. (2004). Zagalna psyhologiya [General Psychology], Kyiv, Ukraine: TsentrUchbovoyi Literatury.

16. Sergeeva, D. N. (2016), Development of Educational Specialist's Creativity in the Process of Conflict Resolution, The Education and Science Journal, (5), 107-122. doi: 10.17853/ 1994-5639-2016-5-107122.

17. Paton, E. (2011), Communication and Creativity: How Does Media Usage Influence Those Who Create Media Texts? Monash University International Journal of Communication, 5,101-116. ISBN-19328036/20110101.
18. Podschuweit, N. (2017), Interpersonal Communication: Media Influence on. The International Encyclopedia of Media Effects., pp. 1-12. doi:10.1002/9781118783764.wbieme0137.

19. Doroshuk, L. A., Novoselov, S. A. (2016), Communicative creativity of the individual as a factor of efficiency communication. Psycologycal-Educational Studies, no. 12, pp. 265-268.

20. Rudenko, L. A. (2015), Communicative culture developing of future specialists in the service industry in vocational education institutions: the monograph. Lviv : Piramida., Ukraine.

21. Ginsburgh, V., Weber, S. (2017), Individual Communicative Benefits. Princeton University Press, doi:10.23943/princeton/9780691136899.003.0006

22. Zotova-Sadylo, O. Y. (2018), Practical Ways of Implementation of the Integrated Approach to Training Professionals in the Field of Professional Communication, Path of Science, (5), 3001-3008. doi: 10.22178 /pos.34-3.

\section{НАВЫКИ МЕЖКУЛЬТУРНОГО ОБЩЕНИЯ : СОСТОЯНИЕ ДЕЛ НА ПРАКТИКЕ \\ О. Ю. Зотова-Садило}

Криворожский Национальный университет,

ул. В. Матусевича, 11, г. Кривой Рог, 50000, Украина. E-mail: hjzotova74@ukr.net

Анализ первоисточников выявил определенную связь между высоким уровнем коммуникативной культуры в контексте межкультурного делового общения и профессиональной реализацией выпускников высших учебных заведений. На основе проведенного анализа коммуникативная культура определена как инструмент продуктивной профессиональной коммуникации. Основой коммуникативной креативности является свободное владение родным и иностранным языками, а именно: соответствующее использование лингвистических единиц (лексики, терминологии и т.д.), способность использовать невербальных элементов в речи, скорость ментальных процессов, развитое воображение и творчество. Цель данного исследования в том, чтобы выявить уровень владения межкультурным общением студентами и предложить пути усовершенствования межкультурной деловой коммуникации. 112 студентов разных специальностей приняли участие в исследовании. Анкетирование подтвердило заинтересованность студентов предметом исследования и понимание ими роли межкультурного делового общения для успешного карьерного роста. Результаты анкетирования продемонстрировали ожидания студентов в аспекте интегрирования в учебный процесс коммуникативного профессионального компонента и коммуникации с целью культурного обмена. Кроме того анализ результатов исследования показал, что только одна третья респондентов подготовлена к общению на иностранном языке. Это доказывает низкий уровень владения иностранными языками на данном этапе. Ответы участников эксперимента подтвердили нашу гипотезу о затребованности специальных курсов, которые направлены на усовершенствование специфических знаний, умений и компетентностей. В соответствии с ожиданиями студентов нами был разработан спецкурс «Деловое общение», имеющий практическую направленность в аспекте повышения межкультурного аспекта коммуникативной культуры.

Ключевые слова: коммуникативная культура; межкультурная коммуникация; анкетирование; коммуникативная креативность; деловое общения.

Стаття надійшла 24.10.2019. 